\title{
The Mediating Effect of Organizational Commitment on the Relationship between Job Satisfaction and Organizational Culture
}

\author{
Adel Mohamed Ali Shurbagi ${ }^{1} \&$ Ibrahim Bin Zahari ${ }^{2}$ \\ ${ }^{1}$ Faculty of Economics, Azzaytuna University, Tarhunah, Libya \\ ${ }^{2}$ Graduate Business School, College of Graduate Studies, Universiti Tenaga Nasional (UNITEN), Malaysia \\ Correspondence: Dr. Adel Mohamed Ali Shurbagi, Faculty of Economics, Azzaytuna University, Tripoli-Libya Box \\ 82502, Tarhunah, Libya. E-mail: Shurbagi@yahoo.com
}

Received: September 5, 2014

Accepted: October 14, 2014

Online Published: November 16, 2014

doi:10.5430/ijba.v5n6p24

URL: http://dx.doi.org/10.5430/ijba.v5n6p24

\begin{abstract}
The purpose of the study was to investigate the effect of organizational commitment as a mediating variable on the relationship between job satisfaction and organizational culture to answer the following questions: Is there any relationship between job satisfaction and organizational culture in oil and gas industry in Libya? Is there any relationship between job satisfaction and organizational commitment in oil and gas industry in Libya? Is there any relationship between organizational culture and organizational commitment in oil and gas industry in Libya? Dose organizational commitment as a mediator variable have any effect on the relationship between job satisfaction and organizational culture in oil and gas industry in Libya? Therefore, a questionnaire was used to collect the data from a sample of 280 employees from oil and gas industry in Libya based on stratified sample sampling. SPSS program was used to reach findings of the study. The empirical results of the current study indicated that the relationship between three variables of the study such as job satisfaction, organizational culture and organizational commitment was positive significant relationship while organizational commitment as a mediating variable effects the relationship between job satisfaction and organizational culture in oil and gas industry in Libya.
\end{abstract}

Keywords: job satisfaction, organizational culture, organizational commitment, Notational Oil Corporation of Libya

\section{Introduction}

National Oil Corporation (NOC) of Libya was established 1970 and it dominates Libya's gas and oil industry, along with a number of smaller subsidiaries, which combined account for approximately half of the country's oil output. National Oil Corporation carries out exploration and production operations through its own affiliated companies, or in participation with other companies under service contracts or any other kind of petroleum investment agreements. This is in addition to marketing operations for oil and gas, locally as well as abroad. NOC has fully owned companies which carry out explorations, developments and production operations, in addition to local and international marketing companies (Sasi, 2008). NOC of Libya is a state-owned company that controls Libya's oil and gas production. The company is the biggest oil producer in Africa. Its mandate is to promote the Libyan economy by undertaking development, management and exploitation of oil resources as well as by participating in planning and executing the general oil policy of the state (NationalOilCorporation, 2008). The choice of NOC of Libya to investigate the relationship between job satisfaction, organizational culture, organizational commitment and the effect of organizational commitment on this relationship in NOC of Libya, because Libya is a member of organization of petroleum exporting countries (OPEC), this holds the largest proven oil reserves and the most important oil-producing countries in Africa and the world. The petroleum sector in Libya is very important because it is the backbone of Libyan economy.

\subsection{Problem Statement}

The oil and gas industry is the most important sector in Libya. Libya is one of the most important oil-producing countries in Africa and in the world, and that the interest in this sector is very important. Therefore, the relationship between job satisfaction, organizational culture and organizational commitment has attracted considerable interest from both academics and practitioners. Much of the interest on these variables is based on the results of the previous 
studies which have asserted that these concepts may have an impact on the organizations performance (Lok and Crawford, 2001; Yousef, 2001 and Shurbagi and Zahari, 2012a).

Furthermore, Yet no study has been conducted to investigate the relationship between these variables and the effect of organizational commitment on this relationship in oil and gas industry. This study, therefore, is unique as it will help to fill this gap in an effort to improve the understanding the relationship between these variables and the effect of organizational commitment on this relationship in Middle East in general and in Libyan setting in particular. Based on the foregoing, the effect of organizational commitment on the relationship between job satisfaction and organizational culture were not explored intensively enough in the literature.

\subsection{Research Objectives}

This paper has four objectives; The first aim is to determine the nature of the relationship between job satisfaction and organizational culture in oil and gas industry in Libya. The second aim is to determine the nature of the relationship between job satisfaction and organizational commitment in oil and gas industry in Libya. The third aim is to determine the nature of the relationship between organizational culture and organizational commitment in oil and gas industry in Libya. The fourth aim is to determine the mediating effect of organizational commitment on the relationship between job satisfaction and organizational culture in oil and gas industry in Libya. Based on the research objectives stated, the following research questions were addressed:

Q1. Is there any relationship between job satisfaction and organizational culture in oil and gas industry in Libya?

Q2. Is there any relationship between job satisfaction and organizational commitment in oil and gas industry in Libya?

Q3. Is there any relationship between organizational culture and organizational commitment in oil and gas industry in Libya?

Q4. Dose organizational commitment as a mediator variable have any effect on the relationship between job satisfaction and organizational culture in oil and gas industry in Libya?

\section{Literature Review}

\subsection{Job Satisfaction}

Job satisfaction has been a phenomenon of intense interest among practitioners and researchers for several decades (Cranny, et al. 1992; Hwang and Chi 2005; Locke 1976 and Spector 1997). Many different definitions have been put, for instance, some definitions focus on the job itself, while others include all the job-related factors. Practitioners and researchers have defined satisfaction as positive feelings or aggressive responses; whereas others have defined it as the gap between the expected gain and the actual gain. Spector, (1985) defined job satisfaction as a cluster of evaluative feelings about the job.

\subsubsection{Determinants of Job Satisfaction}

According to the literature on the job satisfaction there are numerous factors that influence job satisfaction. Worrell (2004), divided these factors into three groups of which the demographic data which includes age, gender, and race; the intrinsic factors that include achievement, recognition, work itself, responsibility, advancement and growth; and the extrinsic factors that include company policy, supervision, relationship with boss, work conditions, relationship with peers and salary. Both the intrinsic factors and extrinsic factors are related to the Two Factor Theory by Herzberg.

\subsection{Organizational Culture}

In fact, the roots of organizational or corporate culture began in the mid nineteenth century Blake and Mouton, (1969) were the first authors who mentioned the link between organizational culture and excellence in the late 1960s. However Hofstede, (1998) pointed out that the concept of organizational culture has became a common parlance two decades after it was used by Blake and Mouton, (1969) an aspect of the organization. Schein, (1992) defined organizational culture as a pattern of shared basic assumptions that the group has earned as it solved its problems of external adoption and internal integration that has worked well enough to be considered valid. Therefore, would be taught to the new members as the correct way to perceive, think and feel in relation to those problems. Schein, (1992) in this definition also describes organizational culture as being deeper than behaviour and artifacts.

\subsubsection{Types of Organizational Culture}

Quinn and Cameron, (1983) and Cameron and Freeman, (1991) had introduced the Competing Values Framework (CVF), which identified four types of culture such as: clan, adhocracy, hierarchy and market culture. The theory of the Competing Values Framework (CVF) suggests two dimensions; the first dimension differentiates the 
effectiveness criteria that emphasize flexibility, discretion, and dynamism from the criteria that emphasize stability, order and control. The second dimension differentiates the effectiveness criteria that emphasize an internal orientation, integration and unity from the criteria that emphasize an external orientation, differentiation and rivalry. The Competing Values Framework (CVF) of (Quinn and Rohrbaugh, 1983) is very useful in organizing and interpreting a wide variety of organizational phenomena. Cameron and Quinn, (2006) from this theory, defined organizational culture as being taken for granted the values, underlying assumptions, expectations, collective memories and definitions present in organization. Each quadrant has been given a label to distinguish its most notable characteristics. Cameron and Quinn from this theory suggest four types of culture in organizations such as clan, adhocracy, hierarchy and market which illustrate in Figure 1.

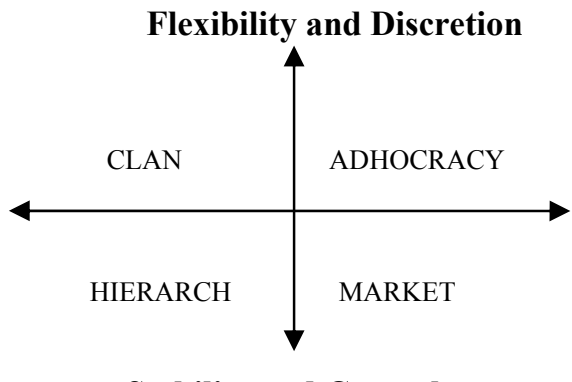

Stability and Control

Figure 1. The competing values framework

\subsubsection{Hierarchy Culture}

Cameron and Quinn, (2006) the first introduce of the hierarchy culture by Weber consists of seven characteristics such as rules, specialization, meritocracy, hierarchy, separate ownership, impersonality, and accountability. These characteristics were deemed highly effective in the accomplishment of the purpose, and were adopted widely in organizations whose major challenge was to generate efficient, reliable, smooth flowing, and predictable output.

\subsubsection{Market Culture}

The term market is not similar to the marketing function or with consumers in the market place. Rather, it refers to a type of organization that functions as a market itself. It is oriented towards the external environment instead of internal affairs. It is focused on transactions with (mainly) external constituencies such as suppliers, customers, contractors, licensees, unions, and regulators. The market operates primarily through economic market mechanisms, mainly the monetary exchange. That is, the major focus of markets is to conduct transactions (exchange, sales, and contracts) with other constituencies to create a competitive advantage. Profitability, bottom-line results, strength in market niches, stretch targets, and secure customer bases are the primary objectives of the organization. Not surprisingly, the core values that dominate such market-type organizations are competitiveness and productivity. Competitiveness and productivity in the market organizations are achieved through the strong emphasis on external positioning and control.

\subsubsection{Clan Culture}

The term clan culture is used because of its similarity to a family-type organization. It seems more like extended families than economic entities. Instead of the rules and procedures of hierarchies or the competitive profit centers of markets, typical characteristics of clan-type firms were teamwork, employee involvement programs and corporate commitment to employees.

\subsubsection{Adhocracy Culture}

A major goal of the adhocracy culture is to foster adaptability, flexibility, and creativity where uncertainty, ambiguity, and information overload are typical. The adhocracy organization may frequently be found in industries such as aerospace, software development, think-tank consulting, and film making. An important challenge for these organizations is to produce innovative products and services and to adapt quickly to new opportunities. Unlike markets or hierarchies, adhocracies do not have a centralized power or an authority relationship. Instead, power flows from individual to individual or from task team to task team, depending on what problem is being addressed at the time (Cameron and Quinn, 2006).

\subsection{Organizational Commitment}

The topic of organizational commitment has become immensely popular in the past two decades through interest of researchers and practitioners in the field of management (Mowday, et al. 1982 and Meyer and Allen, 1991). 
Organizational commitment has been researched in various contexts; including (a) Perceived Organizational Support (O’Driscoll and Randall, 1999), (b) Performance Among Guest Workers (Shawa, et al. 2003), (c) Job Outcomes (Wasti, 2005), (d) Trust, Innovative Behaviour (Lee, 2008), (e) Organizational Culture and Leadership Style (Lok and Crawford, 1999) and (f) Job Satisfaction(Lim, 2010 and Shurbagi and Zahari, 2013b). Some of these studies pointed out that organizational commitment have a positive relationship with these variables.

\subsubsection{Definition of Organizational Commitment}

Organizational commitment, like most other concepts in social sciences, has no single or unique definition. It has been defined differently by different authors. For instance, (Kanter, 1968) described 'cohesion commitment' as 'the attachment of an individual's fund of affectivity and emotion to the group'. While (Buchanan, 1974) conceptualized commitment as a partisan, affective attachment to the goals and values of the organization to one's role in relation to the goals and values, and to the organization for its own sake, apart from its purely instrumental worth. Porter, et, al. (1974) defined organizational commitment as the strength of an individual's identification with and involvement in a particular organization. Such commitment can generally be characterized by at least three factors:

a. A strong belief in and acceptance of the organization's goals and values.

b. A willingness to exert considerable effort on behalf of the organization.

c. A definite desire to maintain organizational membership.

O'Reilly and Chatman (1986) defined commitment as the psychological attachment felt by the person for the organization, reflecting the degree to which the individual internalizes or adopts the characteristics or perspectives of the organization. Mathieu and Zajac, (1990) from their view defined organizational commitment as 'a bond or linking of the individual to the organization'. On the other hand, Meyer and Allen, (1984) Building to Porter, et, al. (1974), definition has been divide the concept of organizational commitment into three components and defined organizational commitment in terms of affective, continuance, and normative.

Affective commitment refers to the employee's emotional attachment to, identification with, and involvement in the organization.

Continuance commitment refers to an awareness of the costs associated with leaving the organization.

Normative commitment reflects a feeling of obligation to continue employment.

Meyer and Allen, (1984) definitional approach, the three components of organizational commitment are components rather than types. Meyer and Allen, (1984) noted the bases are conceptually mutually exclusive.

\subsubsection{Meyer and Allen Model (1991)}

The three components or dimensions of commitment was introduced by Meyer and Allen, (1984) this model was rooted in earlier approaches to organizational commitment which has been done by (Becker, 1960 and Porter, et, al. 1974). Meyer and Allen, (1984) asserted that these three dimensions of commitment is a psychological state which describe as characterizes the employee's relationship with the organization, and the implications for the decision to continue or discontinue membership in the organization. However, it is clear that the nature of the psychological states differ. These three dimensions are affective, continuance and normative describe as follow.

a. Affective commitment refers to the employee's emotional attachment to, identification with, and involvement in the organization. Employees with a strong affective commitment continue employment with the organization because they want to do so (Meyer and Allen, 1984). The most important reason for wanting to remain with the organization is related to the ability of individuals to satisfy their needs at work (Hackman and Oldham, 1976). Allen and Meyer, (1990) have been suggested that the antecedents of affective attachment to the organization divide into four categories: personal characteristics, job characteristics, work experiences and structural characteristics.

b. Meyer and Allen, (1984) proposed the continuance dimension as a better representation of Becker's side-bet approach. It refers to an awareness of the costs associated with leaving the organization. Employees whose primary link to the organization is based on continuance commitment remain because they need to do so. It is related to the benefits associated with staying versus the personal costs associated with leaving such as pensions, seniority, social status, and access to social networks that bind him or her to the organization. These interests would be at risk if the individual left the organization (Dawleya et, al. 2005 and Shahnawaz and Juyal, 2006).

c. Normative commitment was defined as a feeling of obligation to continue employment. Employees with a high level of normative commitment feel that they ought to remain within the organization (Allen and Meyer, 1990). 
Individuals with high normative commitment stay in the organization because they believe it is the right and moral thing to do. Stated differently, they would feel guilty if they left the organization and stay, even if they had to reject better alternatives (Felfea and Yan, 2009). Normative commitment is affected in the main by socialization or culture prior to entry into an organization also would be influenced by the individual's experiences both prior to familial or cultural socialization and following organizational socialization entry into the organization (Wiener, 1982 and Cohen, 2007).

The three dimensions were characterized as a "three component conceptualization of Organizational Commitment" and were described as components rather than types commitment that is, employees can experience each of these psychological states to varying degrees (Allen and Meyer, 1990 and WeiBo, et, al. 2010). Based to the literature the approach of Meyer and Allen, (1984) became the dominant one to the study of commitment (Cohen, 2007 and WeiBo,et, al. 2010).

In the last three decades, academics and researchers have received increasing attention to investigate the relationship between job satisfaction, organizational culture and organizational commitment (Williams and Hazer, 1986; Yousef, 2000; Lok and Crawford 2001 and Lim, 2010). Numerous of these studies in the area of organizational behavior asserted that the relationship between job satisfaction and organizational culture was significant and positive relationship while other studies pointed out that the level of satisfaction was different based on type of dominant culture in the organization (Yousef, 1998; Chen and Francesco, 2000 and Lok and Crawford 2001; Xenikou and Simosi, 2006; Rad and Yarmohammadian, 2006; Hu, et, al., 2009 and Shurbagi and Zahari, 2012b).

On the other hand some scholars investigated the relationship between job satisfaction and organizational commitment the findings asserted that the relationship between these variables was significant and positive relationship (Chen and Francesco 2000; Lok and Crawford 2001; Mathieu and Zajac 1990; Williams and Hazer 1986). Meanwhile, Yiing and Zaman Ahmad, (2009), pointed out that the relationship between job satisfaction and organizational commitment was negative relationship in Education sector in Malaysia. Yousef, (2000) and Lim, (2010) further suggested that job satisfaction and organizational commitment have been theoretically and empirically linked to organizational effectiveness.

Moreover, the previous studies on the field of organizational behavior pointed out that there was a positive correlation between organizational culture and organizational commitment (Zainol, 2009; Zazzali et al 2006; Lim 2010; Shah, 2007). Lok and Crawford, (1999); (2004) and (2007) confirmed that organizational culture was important organizational antecedents of job satisfaction and commitment. These results were supported by Zavyalova and Kucherov, (2010), and Zainol, (2009), who pointed out that organizational culture can influence the organizational commitment and organizational culture have a significant relationship with three dimensions of organizational commitment such as affective, continuance and normative.

In fact, most of these studies investigated the relationship between these variables independently. However, the relationship between job satisfaction, organizational culture, organizational commitment and the effect of organizational commitment as a mediating variable were not explored intensively enough in the literature in general and in oil and gas industry in particular. Furthermore, the study wishes to test the relationship between job satisfaction, organizational culture, organizational commitment and the effect of organizational commitment on this relationship in oil and gas industry in Libya.

\section{Research Methodology}

\subsection{Research Hypotheses}

Based on the literature review, research questions and research objectives the hypotheses of the study are as follow:

H1. There is a relationship between job satisfaction and organizational culture in oil and gas industry in Libya.

$\mathrm{H} 2$. There is a relationship between job satisfaction and organizational commitment in oil and gas industry in Libya.

H3. There is a relationship between organizational culture and organizational commitment in oil and gas industry in Libya.

H4. Organizational commitment has significant effect on the relationship between job satisfaction and organizational culture in oil and gas industry in Libya.

\subsection{Instruments Measurement}

To gather research data in the current study, questionnaire is preferred due to its ability to collect data from respondents within a limited time frame. The instrument consisted four parts such as demographic variables, job 
satisfaction, organizational culture and organizational commitment. Three instruments were used to measure the variables of the study. These instruments are as following:

3.2.1 The Job Satisfaction Survey (JSS) developed by Spector (1997) includes 20 items was used to measure five facets of job satisfaction such as supervision, benefits, rewards, operating procedure and co-workers satisfaction.

3.2.2 The Organizational Culture Assessment Instrument (OCAI) developed by Cameron and Quinn, (2006) as defined by the Competing Values Framework will be implemented in this study. The (OCAI) questionnaire was used to obtain an insight into the organizational culture based on the Organizational Culture Assessment Instrument (OCAI) which divided the organizational culture into four types namely, clan, adhocracy, market and hierarchy culture. This survey instrument requires the sample to respond to six key dimensions. Cameron and Quinn, (2006) the (OCAI) dimensions range from, dominant characteristics, organizational leadership, management of employees, organization glue, strategic emphasis and the criteria for success. Each of the six dimensions has four alternative answers which brings the total items of the (OCAI) questionnaire to 24 items. A Likert scale was used in which the respondents rate each alternative for each item on a scale from ( $1=$ strongly disagree; to $5=$ strongly agree $)$.

3.2.3 Three Components Organizational Commitment Questionnaire (TCOCQ) developed by (Allen and Meyer, 1990) instrument for the multidimensional organizational commitment was adopted for this study to measure organizational commitment. The instrument measures the three dimensions of organizational commitment includes items that measure affective, continuance and normative commitment. There are 24 items in the scale, each dimension of organizational commitment (affective, continuance and normative) has 8 items. A five-point Likert scale will be used with responses ranging from ( $1=$ strongly disagree; to $5=$ strongly agree).

Therefore, the validity and reliability of the instruments which use in this study such as The Job Satisfaction Survey (JSS), The Organizational Culture Assessment Instrument (OCAI) and Three Components Organizational Commitment Questionnaire (TCOCQ) scales have been established through previous researches and the Cranach's Alpha coefficient of the instruments were above 0.70 (Allen and Meyer, 1990; Spector 1997; Twati and Gammack, 2006; Flemming, 2009; Lim, 2010; Shurbagi and Zahari, 2013b and Shurbagi, 2014a). In the current study the Cronbach's Alpha coefficient of job satisfaction, organizational culture and organizational commitment were 0.82; 0.95 and 0.74 respectively.

\subsection{Participants}

To investigate the nature of the relationship between job satisfaction, organizational culture and organizational commitment and the effect of the organizational commitment on this relationship in oil and gas industry in Libya, out of (280) questionnaires were distributed with (250) returning. Of the (250) that returned, (23) questionnaires were rejected, due to insufficient data, resulting in (227) usable questionnaires yielding a response rate of $81 \%$. The stratified sample sampling was used in this study and the sample size has been chosen according to the population of NOC of Libya and the percentage of the employees in each administrative level then the sample was selected randomly. The data were then analyzed using Statistical Package for Social Sciences (SPSS). Details are given in Table 1.

Table 1. Questionnaires distributed

\begin{tabular}{|c|c|c|c|c|}
\hline $\begin{array}{l}\text { Questionnaires } \\
\text { distributed }\end{array}$ & $\begin{array}{l}\text { Questionnaires } \\
\text { returned }\end{array}$ & $\begin{array}{l}\text { Questionnaires } \\
\text { rejected }\end{array}$ & $\begin{array}{l}\text { Questionnaires } \\
\text { usable }\end{array}$ & Percent $\%$ \\
\hline 280 & 250 & 23 & 227 & 81 \\
\hline
\end{tabular}

\section{Empirical Results}

Data was analyzed through descriptive statistical methods with mean, standard deviation, percentage, Correlation Coefficient, Linear, and Multiple Regression. Table 2 contained profile of the respondents of the study. From the Table 2, it was obvious that the respondents between 36-45 years constitute majority of respondents with $104(45.8 \%)$ of the total of respondents while the least respondents with age range goes to those with less than 25 years 6 respondents $(2.6 \%)$. As mentioned earlier, the respondents for this study are employees in gas and oil industry in Libya, the majority of respondents hold Master degrees 77 (33.9\%), while 15 respondents (6.6\%) completed their $\mathrm{PhD}$ degree. $158(69.6 \%)$ of the respondents were married while only 69 respondents $(30.4 \%)$ were single. From total of 227 respondents from gas and oil industry in Libya indicate that, 168 of them (74\%) were male while the remaining was female. 89 respondents (39.2\%), reported that their income was 1101-1500 DL monthly and only two respondents $(0.9 \%)$ their salary was more than 2300 DL monthly. From Table 2 it can be seen that 46 of respondents (20.3\%) have working experiences with gas and oil industry in Libya for 11-15 years, only 25 of respondents (11.0\%) 
have working experiences in oil and gas industry in Libya for 1-5 years. Finally, the majority of respondents with $130(57.3 \%)$ of the total of respondents their boss's function was coordinator. This is followed by 63 respondents $(27.8 \%)$ who their boss's function was director. On the other hand, only 34 respondents $(15 \%)$ their boss's function was observer. All this information has given in Table 2.

Table 2. Profit of the respondents

\begin{tabular}{|c|c|c|c|c|c|}
\hline Contents & Frequency & Percent $\%$ & Contents & Frequency & Percent\% \\
\hline Age & & & Income & & \\
\hline$<25$ years & 6 & 2.6 & $<700 \mathrm{DL}$ & 23 & 10.1 \\
\hline $26-35$ years & 53 & 23.3 & 701-1100 DL & 48 & 21.1 \\
\hline $36-45$ years & 104 & 45.8 & $1101-1500 \mathrm{DL}$ & 89 & 39.2 \\
\hline $46-55$ years & 51 & 22.5 & 1501-1900 DL & 58 & 25.6 \\
\hline$>55$ years & 13 & 5.7 & $1901-2300 \mathrm{DL}$ & 7 & 3.1 \\
\hline Educational level & & & $>2300 \mathrm{DL}$ & 2 & 0.9 \\
\hline Primary School & 10 & 4.4 & Experience of Working & & \\
\hline Secondary School & 56 & 24.7 & $1-5$ years & 25 & 11 \\
\hline Degree & 69 & 30.4 & $6-10$ years & 45 & 19.8 \\
\hline Master Degree & 77 & 33.9 & $11-15$ years & 46 & 20.3 \\
\hline $\mathrm{PhD}$ & 15 & 6.6 & $16-20$ years & 35 & 15.4 \\
\hline Marital status & & & $21-25$ years & 33 & 14.5 \\
\hline Single & 69 & 30.4 & $>25$ years & 43 & 18.9 \\
\hline Married & 158 & 69.6 & Function of your boss & & \\
\hline Gender & & & Coordinator & 130 & 57.3 \\
\hline Male & 168 & 74 & Director & 63 & 27.8 \\
\hline Female & 59 & 26 & Observer & 34 & 15 \\
\hline
\end{tabular}

Table 3 provided the percentages, means, and standard deviations related to the perceptions of respondents of the oil and gas industry in Libya about job satisfaction, organizational culture and organizational commitment in their organization. According to Table 3 the means of five facets of job satisfaction such as were $(3.24,2.79,2.94,2.90$ and 3.05), and the standard deviations of them were $(0.82,0.88,0.92,0.81$ and 0.83$)$. on the other hand the mean of four types of organizational culture such as clan, adhocracy, market and hierarchy culture were $(2.88,2.62,2.85$, and $3.03)$ respectively, while the standard deviations of them were $(0.89,0.72,0.77$ and 0.73$)$ respectively.

Therefore, as can be seen from Table 3 the participants of oil and gas industry in Libya have pointed out the dominant culture in the oil and gas industry in Libya was hierarchy culture, this result consistent with previous studies by (Twati, 2006; Shurbagi and Zahari, 2012a and Shurbagi, 2014b). The most organizations take turns at different cultures. As they progress from the start in a clan culture, they then move to adhocracy culture, then to market culture and finally to the hierarchy culture after they have been established for some time (Shurbagi, 2014b). NOC examined in this study was established in the early 1970s, which mean that they fit in the hierarchy culture at this point.

On the other hand, according to previous table the means of affective, continuance and normative commitment were $(2.93,2.76$ and 2.83$)$ respectively, while the standard deviations of them were $(0.83,0.60$ and 0.80$)$ respectively. Therefore, as can be seen from Table 3 the participants of oil and gas industry in Libya have pointed out the dominant organizational commitment was affective commitment. From discussion above and Table 3 it could be concluded that the dominant culture in oil and gas industry in Libya is hierarchy culture and also the dominant organizational commitment is affective commitment. Table 3 summarizes the mean and standard deviation of these variables.

Table 3. Mean and standard deviation

\begin{tabular}{lcc}
\hline \multicolumn{1}{c}{ Variables \& Dimensions } & M & SD \\
\hline Supervision Satisfaction (SS) & 3.24 & 0.825 \\
Benefits Satisfaction (BS) & 2.79 & 0.881 \\
Rewards Satisfaction (RS) & 2.94 & 0.928 \\
Operation Procedure Satisfaction (OPS) & 2.90 & 0.815
\end{tabular}




\begin{tabular}{llc} 
Co-Workers Satisfaction (CWS) & 0.837 \\
Job Satisfaction (JS) & 3.05 & $\mathbf{0 . 6 5 7}$ \\
\hline Clan Culture (CC) & $\mathbf{2 . 9 8}$ & 0.89 \\
Adhocracy Culture (AC) & 2.88 & 0.72 \\
Market Culture (MC) & 2.62 & 0.77 \\
Hierarchy Culture (HC) & 2.85 & 0.73 \\
Organizational Culture (OC) & 3.03 & $\mathbf{0 . 7 3 2}$ \\
\hline Affective Commitment (AC) & $\mathbf{2 . 8 5}$ & 0.831 \\
Continuance Commitment (CC) & 2.93 & 0.606 \\
Normative Commitment (NC) & 2.76 & 0.801 \\
Organizational Commitment (OC) & 2.83 & $\mathbf{0 . 6 1 4}$ \\
\hline
\end{tabular}

Cronbach Coefficient Alpha was used to test the reliability of the instruments Sekaran, (2005) pointed out that Cronbach Coefficient Alpha of 0.70 or more are considered good. The Cronbach's alpha reliability coefficients for job satisfaction, organizational culture and organizational commitment were $(0.82,0.95$ and 0.74$)$ respectively. Based on the Cronbach Alpha values for facets of job satisfaction, types of organizational culture and component of organizational commitment the instruments are reliable to measure the variables of the study. Table 4 summarizes the reliability of the instrument used in the study.

Table 4. Reliability of the instruments of the study

\begin{tabular}{lcc}
\hline \multicolumn{1}{c}{ Variables \& Dimensions } & Number of items & Cronbach Alpha \\
\hline Supervision Satisfaction (SS) & 4 & 0.763 \\
Benefits Satisfaction (BS) & 4 & 0.824 \\
Rewards Satisfaction (RS) & 4 & 0.756 \\
Operation Procedure Satisfaction (OPS) & 4 & 0.795 \\
Co-Workers Satisfaction (CWS) & 4 & 0.770 \\
Job Satisfaction (JS) & $\mathbf{2 0}$ & $\mathbf{0 . 8 2 3}$ \\
\hline Clan Culture (CC) & 6 & 0.897 \\
Adhocracy Culture (AC) & 6 & 0.855 \\
Market Culture (MC) & $\mathbf{6}$ & 0.856 \\
Hierarchy Culture (HC) & 6 & 0.840 \\
Organizational Culture (OC) & & $\mathbf{2 4}$ \\
\hline Affective Commitment (AC) & 8 & $\mathbf{0 . 9 5 2}$ \\
Continuance Commitment (CC) & 8 & 0.910 \\
Normative Commitment (NC) & 8 & 0.719 \\
Organizational Commitment (OC) & & 0.913 \\
\hline
\end{tabular}

To study the correlation between variables, correlation coefficient was selected to investigate the relationship between these variables. Table 5 below shows that there is a high and significant correlation among the variables of the study. A robust correlation between job satisfaction and organizational culture of 0.689 and is significant at .01 level. A strong relationship was identified between job satisfaction and organizational commitment with a correlation coefficient of 0.619 significance at .01 level. While the correlation between organizational culture and organizational commitment was 0.848 at the same level of significance.

Table 5. Correlation between variables of the study

\begin{tabular}{lccc}
\hline & Job Satisfaction & Organizational Culture & \multicolumn{2}{c}{ Organizational Commitment } \\
\hline Job Satisfaction & 1 & $0.689^{* *}$ & $0.619^{* *}$ \\
\hline Organizational Culture & 1 & $0.848^{* *}$ \\
\hline Organizational Commitment & & & 1 \\
\hline
\end{tabular}


On the same line, based on Table 6 the result of correlation the relationship between facets of job satisfaction types of organizational culture and component of organizational commitment is positive and significant relationship at 0.01 level. Therefore, the highest correlation between facets of job satisfaction and types of organizational culture was found between operation procedure satisfaction and clan culture, $r=0.719$ and the lowest correlation was found between rewards satisfaction and hierarchy culture, $r=0.255$. Besides that, the highest correlation between facets of job satisfaction and component of organizational commitment was found between operation procedure satisfaction and normative commitment, $\mathrm{r}=0.574$ and the lowest correlation between them was found between supervision satisfaction and affective commitment, $r=0.195$. On the other hand, the highest correlation between types of organizational culture and component of organizational commitment was found between market culture and normative commitment, $\mathrm{r}=0.884$ and the lowest correlation was found between adhocracy culture and affective commitment, $\mathrm{r}=0.472$.

Based on the results of the correlation between the variables of the study and their dimensions it could be concluded that the relationship between the variables of the study such as job satisfaction, organizational culture and organizational commitment is significant positive relationship. These results are consistent with previous studies which carried out by Yousef, (2000) who concluded that the relationship between job satisfaction, organizational culture and organizational commitment was positive and significant relationship. Table 6 summarizes the results of correlation.

Table 6. Correlation between dimensions of the variables

\begin{tabular}{|c|c|c|c|c|c|c|c|c|c|c|c|c|}
\hline & $\mathrm{CC}$ & $\mathrm{AC}$ & $\mathrm{MC}$ & $\mathrm{HC}$ & SS & BS & RS & OPS & CWS & $\mathrm{AOC}$ & $\mathrm{COC}$ & NOC \\
\hline $\mathrm{CC}$ & 1 & $0.830 * *$ & $0.897 * *$ & $0.826^{* *}$ & $0.380 * *$ & $0.454 * *$ & $0.258^{* *}$ & $0.719 * *$ & $0.657 * *$ & $0.537 * *$ & $0.607 * *$ & $0.880 * *$ \\
\hline $\mathrm{AC}$ & & 1 & $0.841 * *$ & $0.741 * *$ & $0.362 * *$ & $0.419 * *$ & $0.286^{* *}$ & $0.661 * *$ & $0.648^{* *}$ & $0.472 * *$ & $0.587 * *$ & $0.843 * *$ \\
\hline $\mathrm{MC}$ & & & 1 & $0.824 * *$ & $0.336^{* *}$ & $0.401 * *$ & $0.263 * *$ & $0.660 * *$ & $0.655^{* *}$ & $0.480^{* *}$ & $0.615^{* *}$ & $0.884 * *$ \\
\hline $\mathrm{HC}$ & & & & 1 & $0.375^{* *}$ & $0.386^{* *}$ & $0.255 * *$ & $0.598 * *$ & $0.615 * *$ & $0.520 * *$ & $0.552 * *$ & $0.814 * *$ \\
\hline SS & & & & & 1 & $0.350 * *$ & $0.254 * *$ & $0.399 * *$ & $0.361 * *$ & $0.195 * *$ & $0.266^{* *}$ & $0.345^{* *}$ \\
\hline BS & & & & & & 1 & $0.252 * *$ & $0.456^{* *}$ & $0.411 * *$ & $0.353 * *$ & $0.242 * *$ & $0.413 * *$ \\
\hline $\mathrm{RS}$ & & & & & & & 1 & $0.327 * *$ & $0.384 * *$ & $0.260 * *$ & $0.214 * *$ & $0.269 * *$ \\
\hline OPS & & & & & & & & 1 & $0.623 * *$ & $0.478 * *$ & $0.417 * *$ & $0.574 * *$ \\
\hline CWS & & & & & & & & & 1 & $0.436^{* *}$ & $0.454 * *$ & $0.557 * *$ \\
\hline $\mathrm{AOC}$ & & & & & & & & & & 1 & $0.429 * *$ & $0.443 * *$ \\
\hline $\mathrm{COC}$ & & & & & & & & & & & 1 & $0.648 * *$ \\
\hline NOC & & & & & & & & & & & & 1 \\
\hline
\end{tabular}

\section{Hypotheses Testing}

The hypotheses of the study were tested based on the work of Baron and Kenny (1986); Iacobucci, et, al., (2007); Iacobucci (2012) there are four steps to test the mediating effect. According to this model Simple Linear Regression Analysis was used to test the relationship between the variables of the study such as job satisfaction, organizational culture and organizational commitment. Meanwhile Multiple Linear Regression Analysis was used to test the mediating effect of the mediator variable on the relationship between independent and dependent variables. The results of regression analysis are as follow:

1. From Table 7 the result of linear regression indicates that (job satisfaction) has contributed significantly in the variability of (organizational culture) by $52 \%$ from the total variability. Regression coefficients were found to be significant for job satisfaction and organizational culture that could be confirmed by their respective $t$ statistics and p-value. By looking at the beta coefficient for organizational culture can determine the relationship between job satisfaction and organizational culture. The regression model implied in this study was found statistically significant (P-value $<0.05$ ). Those findings could be suggested that the model was able to fit the data. On the other hand, from the result of regression analysis it could be concluded that the relationship between job satisfaction and organizational culture is a positive relationship Table 7 summarizes the results of Regression Analysis between job satisfaction and organizational culture. 
Table 7. Linear regression analyses between job satisfaction and organizational culture

\begin{tabular}{|c|c|c|c|c|c|}
\hline $\mathbf{R}$ & \multicolumn{2}{|c|}{ R Square } & Adjusted R Square & \multicolumn{2}{|c|}{ Std. Error of the Estimate } \\
\hline \multirow[t]{3}{*}{0.727} & \multicolumn{2}{|c|}{0.528} & 0.526 & \multicolumn{2}{|c|}{0.50} \\
\hline & \multicolumn{2}{|c|}{ Unstandardized } & \multicolumn{3}{|l|}{ Standardized } \\
\hline & B & Std. Error & Beta & $\mathbf{t}$ & Sig. \\
\hline (Constant) & 0.379 & 0.159 & & 2.384 & 0.018 \\
\hline Job satisfaction & 0.829 & 0.052 & 0.727 & 15.871 & 0.00 \\
\hline
\end{tabular}

2. Based on Table 8 the result of linear regression indicates that (job satisfaction) has contributed significantly in the variability of (organizational commitment) by $35 \%$ from the total variability. Regression coefficients were found to be significant for job satisfaction and organizational commitment that could be confirmed by their respective $t$ statistics and p-value. By looking at the beta coefficient for organizational commitment can determine the relationship between job satisfaction and organizational commitment. The regression model implied in this study was found statistically significant (P-value $<0.05$ ). Those findings could be suggested that the model was able to fit the data. On the other hand, from the result of regression analysis it could be concluded that the relationship between job satisfaction and organizational commitment is a positive relationship Table 8 summarizes the results of Regression Analysis between job satisfaction and organizational commitment.

Table 8. Linear regression analyses between job satisfaction and organizational commitment

\begin{tabular}{cccccc}
\hline $\mathbf{R}$ & \multicolumn{2}{c}{ R Square } & Adjusted R Square & \multicolumn{2}{c}{ Std. Error of the Estimate } \\
\hline 0.579 & \multicolumn{2}{c}{0.356} & 0.353 & & 0.494 \\
& \multicolumn{2}{c}{ Unstandardized } & Standardized & & \\
\hline & B & Std. Error & Beta & t & Sig. \\
\hline (Constant) & 1.142 & 0.156 & & 7.311 & 0.00 \\
\hline Job satisfaction & 0.572 & 0.051 & 0.597 & 11.155 & 0.00 \\
\hline
\end{tabular}

3. According on Table 9 the result of linear regression indicates that (organizational culture) has contributed significantly in the variability of (organizational commitment) by $71 \%$ from the total variability. Regression coefficients were found to be significant for organizational culture and organizational commitment that could be confirmed by their respective $\mathrm{t}$ statistics and $\mathrm{p}$-value. By looking at the beta coefficient for organizational commitment can determine the relationship between organizational culture and organizational commitment. The regression model implied in this study was found statistically significant (P-value $<0.05$ ). Those findings could be suggested that the model was able to fit the data. On the other hand, from the result of regression analysis it could be concluded that the relationship between organizational culture and organizational commitment is a positive relationship Table 9 summarizes the results of Regression Analysis between organizational culture and organizational commitment.

Table 9. Linear regression analyses between organizational culture and organizational commitment

\begin{tabular}{|c|c|c|c|c|c|}
\hline $\mathbf{R}$ & \multicolumn{2}{|c|}{ R Square } & Adjusted R Square & \multicolumn{2}{|c|}{ Std. Error of the Estimate } \\
\hline \multirow[t]{3}{*}{0.846} & \multicolumn{2}{|c|}{0.716} & 0.715 & \multicolumn{2}{|c|}{0.328} \\
\hline & \multicolumn{2}{|c|}{ Unstandardized } & \multicolumn{3}{|l|}{ Standardized } \\
\hline & B & Std. Error & Beta & $\mathbf{t}$ & Sig. \\
\hline (Constant) & 0.819 & 0.088 & & 9.345 & 0.00 \\
\hline Organizational culture & 0.711 & 0.030 & 0.846 & 23.846 & 0.00 \\
\hline
\end{tabular}


4. As shown in Table 10 the R Square of 0.79 , means that the data used in the sample accounts for about $79 \%$ of the relationship between job satisfaction, organizational commitment and organizational culture in the population. The probability value obtained is less than the predetermined alpha value (p-value $<.05)$. There exists adequate evidence to show that organizational commitment has a significant effect on the relationship between job satisfaction and organizational culture in Oil and Gas industry in Libya. In addition, organizational commitment contains significant predictors in estimating the relationship between job satisfaction and organizational culture.

Table 10. Multiple regression analyses between varailes of the study

\begin{tabular}{|c|c|c|c|c|c|}
\hline $\mathbf{R}$ & \multicolumn{2}{|c|}{ R Square } & Adjusted R Square & \multicolumn{2}{|c|}{ Std. Error of the Estimate } \\
\hline \multirow[t]{3}{*}{0.890} & \multicolumn{2}{|c|}{0.793} & 0.791 & \multicolumn{2}{|c|}{0.334} \\
\hline & \multicolumn{2}{|c|}{ Unstandardized } & \multicolumn{3}{|l|}{ Standardized } \\
\hline & B & Std. Error & Beta & $\mathbf{t}$ & Sig. \\
\hline (Constant) & -0.492 & 0.118 & & -4.184 & 0.000 \\
\hline Organizational commitment & 0.763 & 0.045 & 0.641 & 16.913 & 0.000 \\
\hline Job satisfaction & 0.393 & 0.043 & 0.344 & 9.082 & 0.000 \\
\hline
\end{tabular}

\section{Conclusion, Limitations \& Recommendations}

This study constituted an exploratory investigation into the relationship between the variables of the study such as job satisfaction, organizational culture and organizational commitment and the effect of organizational commitment on the relationship between job satisfaction and organizational culture in oil and gas industry in a Libyan setting. From the current study it could be concluded that the relationship between the variables of the study such as job satisfaction, organizational culture and organizational commitment and between five facets of job satisfaction, such as (supervision satisfaction, benefits satisfaction, rewards satisfaction, operation procedure satisfaction and co-workers satisfaction), four types of organizational culture such as (clan, adhocracy, market and hierarchy culture), and three component of organizational commitment such as (affective, continuance and normative commitment), was positive and significant relationship and organizational commitment as a mediating variable effect the relationship between job satisfaction and organizational culture in oil and gas industry in Libya. The current study contributes significantly toward developing the understanding of organizational behaviour in Libya and other developing countries which have a few studies in this field. In addition, the study contributes to the knowledge in this area. Despite these features and applications, the current study has some limitations. The current study focuses only on five facets of job satisfaction such as supervision satisfaction, benefits satisfaction, rewards satisfaction, operation procedure satisfaction and co-workers satisfaction, it should also be noted that there are other factors that could affect job satisfaction such as pay, promotion and communication. These factors were not investigated in this study although they might affect job satisfaction. Based on that, future research may be beneficial if more items and better measures are developed in relation to this outcome variable. Therefore future researchers could investigate the effect of organizational commitment on this relationship between these variables such as job satisfaction and organizational culture in both the public and private sectors.

\section{References}

Allen, N. J., \& Meyer, J. P. (1990). The measurement and antecedents of affective, continuance and normative commitment to the organization. Journal of Occupational Psychology, 63, 1-18. http://dx.doi.org/10.1111/j.2044-8325.1990.tb00506.x

Baron., R. M., \& Kenny, D. A. (1986). The moderator-mediator variable distinction in social psychological research: Conceptual strategic and statistical considerations. Journal of Personality and Social Psychology, 51(6), 1173-1182.

Becker, H. S. (1960). Notes on the Concept of Commitment. American Journal of Sociology, 66, 32-42. http://dx.doi.org/10.1086/222820

Blake, R. R., \& Mouton, J. S. (1969). Building a Dynamic Corporation through Grid Organization Development. Addison-Wesley. 
Buchanan, B. (1974). Building organizational commitment: The socialization of managers in work organizations. Administrative Science Quarterly, 19, 533-546. http://dx.doi.org/10.2307/2391809

Cameron, K. S., \& Freeman, S. J. (1991). Cultural congruence, strength, and type: Relationships to effectiveness. Research in organizational change and development, 5(1), 23-58.

Cameron, K. S., \& Quinn, R. E. (2006). Diagnosing and changing organizational culture: Based on the competing values framework. Jossey-Bass.

Chen, Z. X., \& Francesco, A. M. (2000). Employee demography, organizational commitment, and turnover intentions in China: do cultural differences matter? Human Relations, 53(6), 869-887. http://dx.doi.org/10.1177/0018726700536005

Cohen, A. (2007). Commitment before and after: An evaluation and reconceptualization of organizational commitment. Human Resource Management Review, 17, 336-354. http://dx.doi.org/10.1016/j.hrmr.2007.05.001

Cranny, C. J., Smith, P. C., \& Stone, E. (1992). Job satisfaction: How people feel about their jobs and how it affects their performance. New York: Lexington.

Dawleya, D. D., Stephensa, D. R., \& Stephensb, B. D. (2005). Dimensionality of organizational commitment in volunteer workers: Chamber of commerce board members and role fulfillment. Journal of Vocational Behaviour, 67, 511-525. http://dx.doi.org/10.1016/j.jvb.2004.09.001

Felfea, J., \& Yan, H. W. (2009). The impact of workgroup commitment on organizational citizenship behaviour, absenteeism and turnover intention: the case of Germany and China. Asia Pacific Business Review, 15(3), 433-450. http://dx.doi.org/10.1080/13602380802667411

Flemming, P. L. (2009). A study of the relationship between transformational leadership traits and organizational culture types in improving performance in public sector organizations: A Caribbean perspective. Doctoral dissertation, Capella University, USA.

Hackman, J. R., \& Oldham, G. R. (1976). Motivation through the design of work: Test of a theory. Organizational Behavior and Human Performance, 16, 250-279. http://dx.doi.org/10.1016/0030-5073(76)90016-7

Hofstede, G. (1998). Attitudes, values and organizational culture: Disentangling the concepts. Organization studies, 19(3), 477-492. http://dx.doi.org/10.1177/017084069801900305

Hu, Y. J., Yang, F. Y., \& Islam, M. (2009). Leadership behavior, satisfaction, and the balanced scorecard approach: An empirical investigation of the manager-employee relationship at retail institutions in Taiwan. International Journal of Commerce and Management, 20(4), 339-356. http://dx.doi.org/10.1108/10569211011094659

Hwang, I. S., \& Chi, D. J. (2005). Relationships among internal marketing, employee job satisfaction and international hotel performance: An empirical study. International Journal of Management, 22(2), 285-293.

Iacobucci, D. (2012). Mediation analysis and categorical variables: The final frontier. Journal of Consumer Psychology, 22(4), 1-13.

Iacobucci, D., Saldanha, N., \& Deng. X. (2007). A meditation on mediation: Evidence that structural. Equations models perform better than regressions. A meditation on mediation. Journal of Consumer Psychology, 17(2), 140-154.

Kanter, R. M. (1968). Commitment and social organization: A study of commitment mechanisms in utopian communities. American Sociological Review, 33, 499-517. http://dx.doi.org/10.2307/2092438

Lee, S. H. (2008). The Effect of Employee Trust and Commitment on Innovative Behavior in the Public Sector: An Empirical Study. International Review of Public Administration, 13(1), 27-46. http://dx.doi.org/10.1080/12294659.2008.10805110

Lim, T. (2010). Relationships among organizational commitment, job satisfaction, and learning organization culture in one Korean private organization. Asia Pacific Education Review, 11, 311-320. http://dx.doi.org/10.1007/s12564-010-9087-z

Locke, E. A. (1976). The nature and causes of job satisfaction. In M. D. Dunnette (Ed.), Handbook of industrial and organizational psychology. Chicago, IL: Rand McNally College Publishing.

Lok, P., \& Crawford, J. (2001). Antecedents of organizational commitment and the mediating role of job satisfaction. Journal of Managerial Psychology, 16(8), 594-613. http://dx.doi.org/10.1108/EUM0000000006302 
Lok, P., \& Crawford, J. (2004). The effect of organizational culture and leadership style on job satisfaction and organizational commitment. Journal of Management Development, 23(4), 321-335. http://dx.doi.org/10.1108/02621710410529785

Lok, P., Wang, Z. P., Westwood, B., \& Crawford, J. (2007). Antecedents of job satisfaction and organizational commitment and the mediating role of organizational subculture. Working paper, 1-41.

Lok, P., \& Crawford., J. (1999). The relationship between commitment and organizational culture, subculture, leadership style and job satisfaction in organizational change and development. Leadership and Organization Development Journal, 20(7), 365-373.

Mathieu, J. E., \& Zajac, D. M. (1990). A review and meta-analysis of the antecedents, correlates, and consequences of organizational commitment. Psychological Bulletin, 108(2), 171-194. http://dx.doi.org/10.1037/0033-2909.108.2.171

Meyer, J. P., \& Allen, N. J. (1991). A Three-Component Conceptualization of Organizational Commitment. Human Resource Management Review, 1(1), 61-89. http://dx.doi.org/10.1016/1053-4822(91)90011-Z

Meyer, P. J., \& Allen, J. N. (1984). Testing the side-bet theory of organizational commitment: Some methodological considerations. Journal Applied Psychology, 69, 372-378. http://dx.doi.org/10.1037/0021-9010.69.3.372

Mowday, R. T., Porter, L. W., \& Steers, R. M. (1982). Employee-Organization Linkages: The Psychology of Commitment, Absenteeism and Turnover. New York: Academic Press.

National Oil Corporation. (2008). Gale directory of company histories. National Oil Corporation.

O’Driscoll, M. P., \& Randall, D. M. (1999). Perceived Organizational Support, Satisfaction with Rewards, and Employee Job Involvement and Organizational Commitment. Applied Psychology: An International Review, 48(2), 197-209. http://dx.doi.org/10.1111/j.1464-0597.1999.tb00058.x

O'Reilly, C. A., \& Chatman, J. (1986). Organizational commitment and psychological attachment: The effects of compliance, identification and internalization on prosocial behavior. Journal of Applied Psychology, 71, 492-499. http://dx.doi.org/10.1037/0021-9010.71.3.492

Porter, L. W., Steers, R. M., Mowday, R. T., \& Boulian, P. V. (1974). Organizational Commitment, Job Satisfaction, and Turnover among Psychiatric Technicians. Journal of Applied Psychology, 59, 603-609. http://dx.doi.org/10.1037/h0037335

Quinn, R. E., \& Cameron, K. (1983). Organizational life cycles and shifting criteria of effectiveness: Some preliminary evidence. Management science, 29(1), 33-51. http://dx.doi.org/10.1287/mnsc.29.1.33

Quinn, R. E., \& Rohrbaugh, J. (1983). A spatial model of effectiveness criteria: Towards a competing values approach to organizational analysis. Management science, 29(3), 363-377. http://dx.doi.org/10.1287/mnsc.29.3.363

Rad, A. M. M., \& Yarmohammadian, M. H. (2006). A study of relationship between managers' leadership style and employees' job satisfaction. Leadership in Health Services, 19(2), 11-28. http://dx.doi.org/10.1108/13660750610665008

Sasi, T. A. (2008). Antecedents of human resource management practices: Case study analyses of the National Oil Corporation in Libya. Doctoral dissertation, Tun Abdul Razak University. Kuala Lumpur.

Schein, E. H. (1992). Organizational culture and leadership. Jossey-Bass San Francisco.

Sekaran, U. (2005). Research methods for business: A skill building approach. India: Wiley.

Shah, J. (2007). Organizational Culture and Job Satisfaction: An Empirical Study of R and D Organization. Retrieved February 25, 2014, from http://ssrn.com/abstract=1293922

Shahnawaz, M. G., \& Juyal, R. C. (2006). Human Resource Management Practices and Organizational Commitment in Different Organizations. Journal of the Indian Academy of Applied Psychology, 32(3), 171-178.

Shawa, J. D., Deleryb, J. E., \& Abdulla, M. H. A. (2003). Organizational commitment and performance among guest workers and citizens of an Arab country. Journal of Business Research, 56, 1021-1030. http://dx.doi.org/10.1016/S0148-2963(01)00316-2

Shurbagi, A. A. M. (2014a). The Relationship between Transformational Leadership and Organizational Commitment in National Oil Corporation of Libya. 3rd International Conference on Humanities, Biological and Environmental Sciences (pp. 99-105), Abu Dhabi, (UAE). 
Shurbagi, A. A. M., \& Zahari, I. (2012a). The effect of Organizational Culture and the Relationship between Transformational Leadership and Job Satisfaction in Petroleum Sector of Libya. International Business Research, 5(9), 89-97. http://dx.doi.org/10.5430/ijba.v4n4p26

Shurbagi, A. A. M., \& Zahari, I. (2013b). The Relationship between Organizational Commitment and Job Satisfaction in National Oil Corporation of Libya. 2nd International Conference on Business, Economics, and Behavioural Sciences (pp. 17-23), Bali, (Indonesia).

Shurbagi, A. A. M. (2014b). The Relationship between Organizational Culture and Organizational Commitment in National Oil Corporation of Libya, $2^{\text {nd }}$ International Conference on Research in Science, Engineering and Technology, (pp. 212-218) Dubai, (UAE).

Shurbagi, A. A. M., \& Zahari, I. (2012b). The Relationship between Organizational Culture and Job Satisfaction in National Oil Corporation of Libya, International Journal of Humanities and Applied Sciences, 1(3), 88-93.

Spector, P. E. (1985). Measurement of human service staff satisfaction: Development of the Job Satisfaction Survey. American journal of community psychology, 13(6), 693-713. http://dx.doi.org/10.1007/BF00929796

Spector, P. E. (1997). Job satisfaction: Application, assessment, cause, and consequences. Sage Publications, Inc.

Twati, J. M. (2006). Societal and organisational culture and the adoption of management information systems in Arab countries. Doctoral dissertation, Griffith University, Australia.

Twati, J. M., \& Gammack, J. G. (2006). The impact of organizational culture innovation on the adoption of IS/IT: the case of Libya. Journal of enterprise information management, 19(2), 175-191. http://dx.doi.org/10.1108/17410390610645076

Wasti, S. A. (2005). Commitment profiles: Combinations of organizational commitment forms and job outcomes. Journal of Vocational Behaviour, 67, 290-308. http://dx.doi.org/10.1016/j.jvb.2004.07.002

WeiBo, Z., Kaur, S., \& Jun, W. (2010). New development of organizational commitment: A critical review (1960 2009). African Journal of Business Management, 4(1), 12-20.

Wiener, Y. (1982). Commitment in organizations: A normative view. Academy of Management Review, 7, 418-428.

Williams, L. J., \& Hazer, J. T. (1986). Antecedents and consequences of satisfaction and commitment in turnover models: A reanalysis using latent variable structural equation methods. Journal of applied psychology, 71(2), 219-231. http://dx.doi.org/10.1037/0021-9010.71.2.219

Worrell, T. G. (2004). School psychologists's job satisfaction: ten years later of the Virginia Polytechnic Institute and State University doctoral dissertation Virginia Tech, Virginia.

Xenikou, A., \& Simosi, M. (2006). Organizational culture and transformational leadership as predictors of business unit performance. Journal of Managerial Psychology, 21(6), 566-579. http://dx.doi.org/10.1108/02683940610684409

Yiing, L. H., \& Zaman, A. K. (2009). The moderating effects of organizational culture on the relationships between leadership behavior and organizational commitment and between organizational commitment and job satisfaction and performance. Leadership and Organization Development Journal, 30(1), 53-86. http://dx.doi.org/10.1108/01437730910927106

Yousef, D. A. (1998). Correlates of perceived leadership style in a culturally mixed environment. Leadership \& Organization Development Journal, 19(5), 275-284. http://dx.doi.org/10.1108/01437739810234341

Yousef, D. A. (2000). Organizational commitment: a mediator of the relationships of leadership behaviour with job satisfaction and performance in a non-western country. Journal of Managerial Psychology, 15(1), 6-24. http://dx.doi.org/10.1108/02683940010305270

Yousef, D. A. (2001). Islamic work ethic: A moderator between organizational commitment and job satisfaction in a cross-cultural context. Personnel Review, 30(2), 152-169. http://dx.doi.org/10.1108/00483480110380325

Zainol, N., N. (2009). Islamic Work Ethics, Organizational Culture and Organizational Commitment: A Study of Employees at Majlis Amanah Rakyat. Unpublished master thesis, University Utara Malaysia, Kedah.

Zavyalova, E., \& Kucherov, D. (2010). Relationship between organizational culture and job satisfaction in Russian business enterprises. Human Resource Development International, 13(2), 225-235.

Zazzali, J., L., Alexander, J., A., Shortell, S., M., \& Burns, L., R. (2006). Organizational Culture and Physician Satisfaction with Dimensions of Group Practice. Health Research and Educational Trust, 10, 1475-6773. 